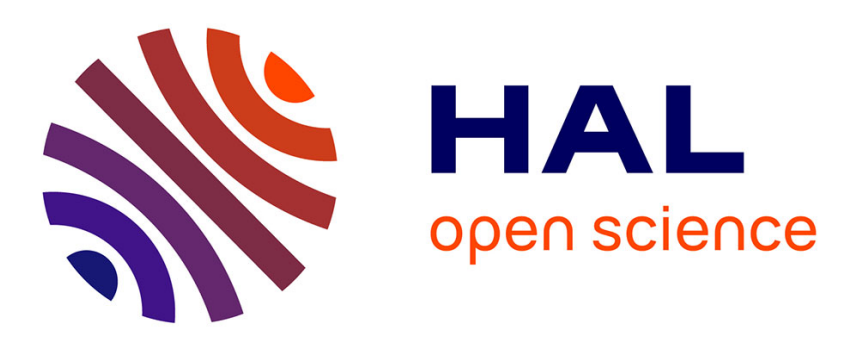

\title{
How much structuring is beneficial with regard to examination scores? A prospective study of three forms of active learning
}

\author{
Claus Reinhardt, Evelyne Rosen-Reinhardt
}

\section{- To cite this version:}

Claus Reinhardt, Evelyne Rosen-Reinhardt. How much structuring is beneficial with regard to examination scores? A prospective study of three forms of active learning . Advances in Physiology Education, 2012, 36 (3), pp.207-212. 10.1152/advan.00108.2011 . hal-01592435

HAL Id: hal-01592435

https://hal.univ-lille.fr/hal-01592435

Submitted on 25 Sep 2017

HAL is a multi-disciplinary open access archive for the deposit and dissemination of scientific research documents, whether they are published or not. The documents may come from teaching and research institutions in France or abroad, or from public or private research centers.
L'archive ouverte pluridisciplinaire HAL, est destinée au dépôt et à la diffusion de documents scientifiques de niveau recherche, publiés ou non, émanant des établissements d'enseignement et de recherche français ou étrangers, des laboratoires publics ou privés. 


\title{
How much structuring is beneficial with regard to examination scores?
}

\section{A prospective study of three forms of active learning}

\author{
Claus H. Reinhardt ${ }^{1,2}$ and Evelyne N. Rosen ${ }^{3}$ \\ ${ }^{1}$ Teacher Training College, Köln, Germany; ${ }^{2}$ Centre of Dental Medicine, University of Cologne, Köln, Germany; \\ and ${ }^{3}$ International Foreign Students Department, University Lille 3, Domaine Universitaire du "Pont de Bois," Villeneuve \\ d'Ascq cedex, France
}

Submitted 10 November 2011; accepted in final form 19 June 2012

Reinhardt CH, Rosen EN. How much structuring is beneficial with regard to examination scores? A prospective study of three forms of active learning. Adv Physiol Educ 36: 207-212, 2012; doi:10.1152/advan.00108.2011.-Many studies have demonstrated a superiority of active learning forms compared with traditional lecture. However, there is still debate as to what degree structuring is necessary with regard to high exam outcomes. Seventy-five students from a premedical school were randomly attributed to an active lecture group, a cooperative group, or a collaborative learning group. The active lecture group received lectures with questions to resolve at the end of the lecture. At the same time, the cooperative group and the collaborative group had to work on a problem and prepare presentations for their answers. The collaborative group worked in a mostly self-directed manner; the cooperative group had to follow a time schedule. For the additional work of preparing the poster presentation, the collaborative and cooperative groups were allowed $50 \%$ more working time. In part 1, all groups worked on the citric acid cycle, and in part 2, all groups worked on molecular genetics. Collaborative groups had to work on tasks and prepare presentations for their answers. At the end of each part, all three groups were subjected to the same exam. Additionally, in the collaborative and cooperative groups, the presentations were marked. All evaluations were performed by two independent examiners. Exam results of the active lecture groups were highest. Results of the cooperative group were nonsignificantly lower than the active lecture group and significantly higher than the collaborative group. The presentation quality was nonsignificantly higher in the collaborative group compared with the cooperative group. This study shows that active lecturing produced the highest exam results, which significantly differed from collaborative learning results. The additional elaboration in the cooperative and collaborative learning setting yielded the high presentation quality but apparently could not contribute further to exam scores. Cooperative learning seems to be a good compromise if high exam and presentation scores are expected.

active learning; cooperative learning; collaborative learning; active lecture; exam scores

MANY STUDIES HAVE INDICATED that active forms of learning are more effective than traditional lecture, which is considered as a more passive form of learning $(1,4,6,7,9,10,13,14,16$, $18,19,25)$. In particular, the advantages of active learning forms with regard to conceptual understanding have been emphasized (1, 4, 24, 25). Moreover, active learning forms, especially cooperative ones, have been associated with numerous additional positive effects. Some of these desirable effects are increased student engagement $(1,16,25)$, elevated selfbelief $(16,25)$, and improved self-perceived competence (16, $25)$. Improvement of these factors does not only help students

Address for reprint requests and other correspondence: C. H. Reinhardt, Barthelstrasse 36, Köln 50823, Germany (e-mail: drcreinhar@aol.com). to feel significantly better compared with teacher-centred approaches $(1,16,18,26)$ but are also important factors for success regarding examinations and qualifications (14). Moreover, cooperative learning forms can help to create and ameliorate relationships between students and teachers $(6,25)$ and also train social skills $(3,4,16,17,25)$.

However, with regard to exam scores, not all studies support this positive view $(2,11,12,20,26)$. Many potential reasons for these results have been discussed, and some authors have argued that some studies did not respect standards for "highquality cooperative learning" $(9,25,26)$. It seems to be important that learning is self-directed $(4,8,25)$, learners are motivated $(6,8,9,25,26)$, learners are mutually dependent $(18,25)$, learners take responsibility for their learning $(9,24$, 26), learners are experienced with cooperative learning forms $(11,26)$, and learners are allowed sufficient time $(6,18,25)$.

In the present study, we wanted to examine to what extent structuring is beneficial in active learning forms. Our study continues the research of Banerjee (2), who compared traditional lecture to cooperative learning forms, and Harskamp and Ning Ding (11), who tried to explore what extent of structuring of the collaborative process is needed. In their study (11), they compared a group that solved problems individually with a group that was provided additionally with hints to structure their problem-solving process. This study showed only minor advantages for collaborative learning with hints.

In view of these results, we enlarged the scale comparing learners with very little structuring (collaborative learning) with intermediate structuring (cooperative learning) and high structuring (active lecture). Collaborative learning and cooperative learning are often used interchangeably; in this article, we refer to the definition of Ventamiglia (27), which points out that cooperative learning groups rely on the teacher to organize learning activities and provide sources and that collaborative groups create their own direction and sources.

As mentioned above, for this study, we tried to respect the "standards of quality" for collaborative/cooperative learning stated above: all participants had 6 mo of experience in collaborative and cooperative learning. We used challenging problems (9): "counselling ways on how to lose weight using the acid circle" and to "identify a murderer by means of Southern blot analysis." The collaborative and cooperative learning groups had to exhibit their results by a poster presentation. This multipurpose task (research, poster design, and presentation) was intended to create a setting where learners could contribute their different talents and therefore be mutually dependent. Each learner had to document his/her contributions in a miniportfolio to enhance responsibility for the 
learning process. The collaborative group was free to organize their learning activity with regard to the multipurpose task; the cooperative group was free to determine their learning but had to follow a stricter time schedule with different subtasks.

Following the advice of several authors to provide sufficient learning time for collaborative and cooperative learning $(6,17,18$, $25,26)$, the collaborative and cooperative groups were allowed $50 \%$ more learning time for performing their extra task.

The degree of structuring as well as the respect of the standards of collaborative and cooperative learning differ in the three arms of this study (active lecture, cooperative learning, and collaborative learning): active lecture is very structured and respects, to a smaller extent, the standards of collaborative and cooperative learning (especially with respect to self-direction); the cooperative learning takes a middle position; and, finally, the collaborative learning is less structured and respects most of the standards.

The aim of this study was to compare the relative effectiveness of three different active learning forms (collaborative learning, cooperative learning, and active lecture) on achievement in physiology at a further education college. The primary outcome parameter was cognitive achievement with regard to a written class test.

The second outcome parameter, which applied only to the collaborative and cooperative groups, was the quality of their poster presentations.
Our hypothesis was that if we respect the standards of collaborative and cooperative learning as described in the literature $(6,8,9,18,25,26)$ and provide sufficient learning time $(6,17,18,25,26)$, cooperative and especially collaborative learners should produce the highest exam scores.

\section{METHODS}

Seventy-five students of three physiology courses (mean age: $20.1 \pm 1.3 \mathrm{yr}$ ) at further education in college (Bonn, Germany) gave their written consent that they could be filmed and their anonymous test results statistically analyzed. Ethical approval and protocol authorization were given by the college's Institutional Review Board. All students were used to active lectures and cooperative and collaborative work for 6 mo.

All participants passed an entry test (cell biology). Participants were stratified with regard to their scores and then randomly distributed to the three groups so that the different grades were equally distributed in each group and the mean score (based on the entry test) was the same in all three groups. All three groups worked on the same two contents, used the same textbook (21), and were taught by the same teacher.

The contents in part 1 were the "citric acid cycle" and in part 2 "DNA fingerprinting" (Fig. 1). The active lecture group covered these topics only; the collaborative and cooperative groups were assigned to design posters that answered the tasks with regard to parts 1 and 2 . In part 1 , their task was whether sprinting or jogging was more beneficial for losing weight. The answer to this question was to be based on the

\begin{tabular}{|c|c|c|c|c|c|}
\hline \multicolumn{6}{|l|}{ Part 1} \\
\hline \multicolumn{2}{|c|}{$\begin{array}{l}\text { active lecture group } \\
\mathrm{n}=25\end{array}$} & \multicolumn{2}{|c|}{ cooperative group } & \multicolumn{2}{|c|}{ collaborative group } \\
\hline Topic: & citric acid cycle & Topic: & citric acid cycle & Topic: & citric acid cycle \\
\hline Time & $315 \mathrm{~min}$ & Task & $\begin{array}{l}\text { Using the citric acid } \\
\text { cycle to explain what } \\
\text { form of sport is more } \\
\text { efficient to lose weight }\end{array}$ & Task & $\begin{array}{l}\text { Using the citric acid } \\
\text { cycle to explain what } \\
\text { form of sport is more } \\
\text { efficient to lose weight }\end{array}$ \\
\hline A scosmont & Fram & Time & $495 \mathrm{~min}$ & Time & $495 \mathrm{~min}$ \\
\hline Assessment & Exam & Assessment & $\begin{array}{l}\text { Exam } \\
+ \text { poster presentation }\end{array}$ & Assessment & $\begin{array}{l}\text { Exam } \\
+ \text { poster presentation }\end{array}$ \\
\hline \multicolumn{6}{|l|}{ Part 2} \\
\hline \multicolumn{2}{|c|}{ active lecture group } & \multicolumn{2}{|c|}{ cooperative group } & \multicolumn{2}{|c|}{ collaborative group } \\
\hline \multirow[t]{2}{*}{ Topic: } & $\begin{array}{l}\text { DNA and DNA } \\
\text { Fingerprinting }\end{array}$ & Topic: & $\begin{array}{l}\text { DNA and DNA } \\
\text { Fingerprinting }\end{array}$ & Topic: & $\begin{array}{l}\text { DNA and DNA } \\
\text { Fingerprinting }\end{array}$ \\
\hline & & Task & $\begin{array}{l}\text { Find out who was the } \\
\text { murderer by using a } \\
\text { southern blot model }\end{array}$ & Task & $\begin{array}{l}\text { Find out who was the } \\
\text { murderer by using a } \\
\text { southern blot model }\end{array}$ \\
\hline Time & $315 \min$ & Time & $495 \mathrm{~min}$ & Time & $495 \min$ \\
\hline Assessment & Exam & Assessment & $\begin{array}{l}\text { Exam } \\
+ \text { poster presentation }\end{array}$ & Assessment & $\begin{array}{l}\text { Exam } \\
+ \text { poster presentation }\end{array}$ \\
\hline
\end{tabular}

Fig. 1. Flowchart describing parts 1 and 2. 
citric acid cycle. In part 2 , their task was to find out who was a murderer $20 \mathrm{yr}$ ago. The answer to this question was to be based on DNA fingerprinting.

As described in the Introduction, the learning time for the active lecture group and the collaborative and cooperative learning groups was different. Because of their additional work load (i.e., design the appropriate poster and preparation for presentation), the collaborative and cooperative groups were accorded an additional $180 \mathrm{~min}$, totaling up to $495 \mathrm{~min}$, respectively, to accomplish their tasks in parts 1 and 2. The lecture group was accorded 315 min, respectively.

All groups were informed that at the end of each part an individual exam had to be passed. Moreover they were given an information sheet with general information regarding the topics of the test. A sample question for each level of taxonomy as well as a sample solution was provided.

\section{Active Lecture Group}

The active lecture group received several lectures regarding the course subjects. About $15 \mathrm{~min}$ of each lecture were reserved for active teaching forms [think-pair (square)-share, concept test, quick thinks, multiple-choice questions, and minute papers (see Ref. 17)].

\section{Collaborative and Cooperative Groups}

Conditions that were identical for the collaborative and cooperative groups are summarized below; the particularities of the collaborative and cooperative approaches are specified in their following subsections.

Students in the collaborative and cooperative learning groups benefited from one short lecture giving a general overview of the topics of parts 1 and 2, respectively. The collaborative and cooperative learning groups were then divided into assigned subteams of four members. This team assignment allowed a heterogeneous group composition that assured that each group had one student with high exam scores in the pretest. After the initial lecture, the subteams learned at work stations providing additional text books, dictionaries, a computer with an internet connection, and access to the video material, which was used for the active lecture. Moreover, a teaching staff member was available for specific questions and tutoring. The role of the teacher was confined to giving an overview of the contents, providing the tasks for parts 1 and 2, clarifying doubts, and periodic group monitoring and discussion with each group. Both groups were provided a guideline regarding the poster presentation specifying the criteria for marking. All participants of the collaborative and cooperative groups had to document their contribution to the processing of the task on a worksheet called the miniportfolio.

Collaborative learning group. Apart from the restrictions described above, the collaborative group was free to determine their learning process and interim outcome goals independently.

Cooperative learning group. The cooperative learning group was to observe the restrictions mentioned above. They could only determine their learning process; the interim outcome goals and time schedule were teacher centered. The time schedule defined the time allowed for the processing of each subtask (i.e., literature research, preliminary draft of their problem solving, poster design, and preparation of the poster presentation). Moreover, the final $60 \mathrm{~min}$ of their working time were reserved for answering questions regarding the contents of parts 1 and 2 . The tasks were the same that were used for the active lecture group. The tasks had to be answered in a think-pair (square)-share manner.

\section{Assessment Tools}

The collaborative work was filmed. Students were used to this procedure because video-based group process analysis was performed extensively before.

The next week, both groups were assigned to take an identical required class test in the hall of the institution on the same day. The content validation of the tests was done by other members of the physiology teaching staff and also by administering the tests to the students of the same course who did not participate in this study. Tests had $40 \%$ of items that could assess knowledge, $30 \%$ of items that could assess comprehension and application, and 30\% of items that could assess synthesis and evaluation. Three sample test items, one item from each test, are provided in the APPENDIX. The test items in the three tests were neither discussed nor solved in the classes before the test. The tests were scored by two independent teachers who were blinded as to which group they were examining based on a scoring key prepared on acceptable answers. The answers for each test item were divided into parts, and partial credit for each part was indicated in the scoring key. A $100-91 \%$ score was marked as very good (15-13 points), a $90-81 \%$ score was marked as good (12-10 points), a $80-66 \%$ score was marked as satisfactory (9-7 points), a $65-51 \%$ score was marked as passed (6-4 points), and a $<50 \%$ score was marked as not satisfactory (3-1 points).

The interexaminer reliability was evaluated for each test by calculating the $\kappa$-value.

Posters designed by the collaborative and cooperative teams were marked according to a scoring key, which included the correct presentation of facts $(40 \%)$, usage and explication of technical terms $(15 \%)$, presentation in a logical order (research question, methods, results, and discussion, $10 \%$ ), design quality of the poster (20\%), and nonverbal presentation quality (i.e., contact with the audience, gestures, and modulation, $15 \%$ ). The poster presentations were filmed and were marked by two blinded independent examiners. The interexaminer reliability was assessed for each test by calculating the к-value.

\section{Statistical Analysis}

Statistical analysis was performed with distribution-free methods because parametric assumptions were not met with the sample size used. Comparison of each participant's score in parts 1 and 2 was performed by a Wilcoxon signed-rank test; comparisons of the active lecture group with the cooperative and collaborative groups and comparisons of the cooperative group with the collaborative group were performed using a Mann-Whitney test. Interexaminer reliability was calculated using the $\mathrm{\kappa}$-test.

\section{RESULTS}

Table 1 shows all marks obtained from the students. Exam scores were the primary outcomes of the active lecture and collaborative groups; poster creation and presentation were the secondary outcome, which was performed by the collaborative groups only.

Table 2 shows statistical comparisons with regard to the different approaches (active lecture, cooperative, and collaborative learning) of parts 1 and 2. Table 3 shows a longitudinal comparison of the results of the different approaches (active lecture, cooperative, and collaborative learning).

The main findings regarding the primary outcome parameter were a persistant significant difference with regard to exam scores between the active lecture group compared with the collaborative group in part $1(P=0.009)$ and part $2(P=$ 0.05), respectively. Cooperative learning groups scored higher than collaborative groups: in part 1, cooperative learning groups obtained significantly better results $(P=0.05)$; in part 2 , cooperative learning groups attained much better results but did not differ significantly $(P=0.056)$.

Comparison of the active lecture group with the cooperative learning group differed nonsignificantly in part $1(P=0.36)$ and part $2(P=0.2)$, respectively. 
Table 1. Descriptive statistics regarding parts 1 and 2

\begin{tabular}{|c|c|c|c|c|c|}
\hline \multirow[b]{2}{*}{ Approach } & \multirow[b]{2}{*}{ Number } & \multicolumn{4}{|c|}{ Marks } \\
\hline & & Minimum & Maximum & Mean (SD) & $\kappa$ value \\
\hline \multicolumn{6}{|l|}{ Part 1: citric acid cycle } \\
\hline Active lecture cognitive test & 25 & 3.00 & 14.00 & $9.92(2.78)$ & 0.77 \\
\hline Cooperative cognitive test & 25 & 3.00 & 13.00 & $9.2(2.85)$ & 0.76 \\
\hline Cooperative poster & 25 & 6.00 & 14.00 & $10.96(2.57)$ & 0.73 \\
\hline Collaborative cognitive test & 25 & 3.00 & 13.00 & $7.4(3.46)$ & 0.76 \\
\hline Collaborative poster & 25 & 7.00 & 15.00 & $11.64(1.78)$ & 0.74 \\
\hline \multicolumn{6}{|l|}{ Part 2: DNA fingerprinting } \\
\hline Active lecture cognitive test & 25 & 4.00 & 14.00 & $10.68(2.34)$ & 0.72 \\
\hline Cooperative cognitive test & 25 & 3.00 & 14.00 & $9.76(2.54)$ & 0.74 \\
\hline Cooperative poster & 25 & 7.00 & 14.00 & $11.16(1.7)$ & 0.72 \\
\hline Collaborative cognitive test & 25 & 3.00 & 14.00 & $7.9(3.53)$ & 0.76 \\
\hline Collaborative poster & 25 & 7.00 & 15.00 & $11.76(1.8)$ & 0.73 \\
\hline
\end{tabular}

Concerning high taxonomy tasks (synthesis and evaluation), the cooperative and collaborative groups tended to have better results; however, the differences did not reach significance.

As for the second outcome parameter, the quality of the poster presentation, there was a nonsignificant difference between the collaborative group and cooperative group in part 1 $(P=0.149)$ and part $2(P=0.685)$, respectively.

Analysis of the longitudinal outcome produced some improvement from part 1 to part 2 regardless of the approach. The greatest increase was yielded by the collaborative group from part 1 to part $2(P=0.062)$. This increase was realized predominately by the greatest-performing third of the group.

Interexaminer reliability was calculated using the $\kappa$-test; к-values ranged from 0.72 to 0.77 for the cognitive tests and from 0.72 to 0.74 for the poster presentations.

\section{DISCUSSION}

Our results confirm that active lecture is a powerful learning method $(1,13,22)$. Moreover, in agreement with previous studies $(2,11,12,20,26)$, our results show that if exam scores are considered separately, active lecture seems to have an advantage over collaborative learning forms. These results seem to be perfectly summarized by Richardson's view: "do not dump the didactic lecture; fix it" (22). Moreover, our study confirms that with regard to exam scores, a structured learning environment seems to be beneficial (11).

Table 2. Comparison between the active lecture, collaborative, and cooperative learning groups

\begin{tabular}{clc}
\hline \multicolumn{1}{c}{ Approach } & \multicolumn{1}{c}{ Approach } & P Value \\
\hline $\begin{array}{c}\text { Part 1 } \\
\text { Active lecture cognitive test }\end{array}$ & Cooperative cognitive test & 0.364 \\
Active lecture cognitive test & Collaborative cognitive test & 0.009 \\
Cooperative cognitive test & Collaborative cognitive test & 0.05 \\
Cooperative poster & Collaborative poster & 0.149 \\
presentation & presentation & \\
Part 2 & & \\
Active lecture cognitive test & Cooperative cognitive test & 0.198 \\
Active lecture cognitive test & Collaborative cognitive test & 0.005 \\
Cooperative cognitive test & Collaborative cognitive test & 0.056 \\
Cooperative poster & Collaborative poster & 0.197 \\
presentation & presentation & \\
\hline
\end{tabular}

$P$ values were determined by a Mann-Whitney test.
However, with regard to the special conditions in this study (experienced participants with cooperative and collaborative learning, a challenging problem, a learning environment that encouraged mutual dependence and responsibility of the learners, options for self-directed learning, and finally the 1.5 -fold increased learning time), it is astonishing that cooperative and collaborative groups did not perform better. Despite this optimized learning setting for collaborative groups, there was a significant difference between the collaborative and active lecture group in part $1(P=0.009)$ and part $2(P=0.005)$ regarding exam scores. The fact that collaborative groups performed worse is bewildering. Moreover, the great difference between exam scores ( 7.4 and 7.9 points, respectively) and poster presentation marks (11.64 and 11.76 points, respectively), especially in the collaborative learning group, is stunning. These high results of the poster presentation indicate that the relative low exam scores with collaborative learners seem to be neither due to nonengagement with the task $(11,25)$, and with regard to the miniportfolio, nor to free riding $(9,25)$. However, accepting these indicators that collaborative and cooperative participants engaged actively, it seems that the acquisition of further competences, such as communication and collaborative skills, does not seem to have a potential to improve exam scores, at least not for all learners. The analysis of the collaborative learning group shows that in parts 1 and 2 , high marks (13 and 14 points) were achieved by several (good) learners; however, poor learners realised only low grades (3 and 4 points). This discrepancy is reflected in the high SD of the collaborative learning group. Moreover, the relatively important longitudinal increase in exam scores from part 1 to part 2 was mainly realized by the good learners who could ameliorate their grades. Apparently, collaborative learning that

Table 3. Longitudinal comparison of the active lecture, collaborative, and cooperative learning groups

\begin{tabular}{lll}
\hline \hline \multicolumn{1}{c}{ Part 1 } & \multicolumn{1}{c}{ Part 2 } & P Value \\
\hline Approach & & \\
Active lecture cognitive test & Active lecture cognitive test & 0.508 \\
Cooperative cognitive test & Cooperative cognitive test & 0.077 \\
Collaborative cognitive test & Collaborative cognitive test & 0.062 \\
Cooperative poster & Cooperative poster & 0.405 \\
Collaborative poster & Collaborative poster & 0.225 \\
\hline
\end{tabular}

$P$ values were determined by a Wilcoxon signed-ranks test. 
stresses responsibility (which, in this study, was assured by the miniportfolio, where all participants had to document their contributions) does not push poor learners to laze around but invites them to engage in nonexam-related activities (such as poster design). The failure of students to change their strategies in part 2 despite their poor results in part 1 confirms that self-assessment and reflection is a difficult task (15) that cannot be easily achieved by poor learners.

These learners seem to benefit enormously from structuring. The cooperative approach obliged learners to reserve $<15 \%$ of their learning time for answering content-related questions. This small investment of time resulted in a significant $(P=$ 0.05 ) difference in exam scores for cooperative learning groups compared with collaborative learning groups in part 1 ; in part 2 , the difference diminished but remained almost significant $(P=0.056)$. Moreover, this structuring resulted in exam scores that differed nonsignificantly from exam scores of active lecture learners in part $1(P=0.364)$ and part $2(P=0.198)$, respectively. These results convinced us to reject our hypothesis. Our results seem to indicate that structuring should be considered as a key factor with regard to high exam scores.

When we compared the poster presentation results of the collaborative and cooperative groups, the results were almost similar $(P=0.149$ and 0.197 , respectively). Thus, the cooperative group participants could yield a comparable high presentation quality and, at the same time, realized a significant difference in exam scores output, which was almost as high as the exam scores of the lecture group.

Acknowledging that communication and collaborative skills are increasingly recognized as highly important elements of medical expertise $(14,23,25)$, the cooperative learning approach appears to be a reasonable compromise if high exam scores and social skills are to be facilitated. If collaborative learning is opted for, it seems worthwhile to propose some form of support for poorer learners. Recent computerized learning tools can provide this individual scaffolding and may therefore provide a good balance of challenge and support for these learners (11).

\section{Limitations}

The further education college where the study took place is a premedical school. This implicates that the results of this study should be applicable to preclinical students; however, transfer of these results to clinical students should be done cautiously. The results of this study were gained with a seminar-like sample size. This sample size might tend to overestimate the effect of the active lecture because members of this relatively small group benefited from a closer contact to the lecturer, which would be difficult to realize in a large lecturing theater. On the other hand, the limited number of students enrolled allowed us to review all student production twice by two independent examiners, which is advisable for higher learning tasks and especially for the poster presentation (3). In the present study, we can support our results by a good interexaminer reliability (with $\kappa$-values from 0.72 to 0.77 ).

We cannot completely rule out that the inferior test results of the cooperative and collaborative learning environment might have been due to case studies that were not challenging enough. However, two facts seem to indicate that this should not be a major confounding factor: 1 ) these differences were consistent for parts 1 and 2 of this study and 2) test results from the cooperative learning environment were considerably higher than those of the collaborative learning environment even though they used the same case study.

\section{Conclusions}

The results of this study indicate that an active lecture seems to be superior to a collaborative learning setting if exam scores are examined exclusively and learning time restrictions are considered. Apparently, additional acquisition of communication and collaborative skills do not directly contribute to exam scores. When 1.5-fold the learning time was allowed, the cooperative learning approach yielded a comparable exam score to the active lecture. The more structured cooperative learning approach yielded significantly higher exam scores than the collaborative approach and was especially beneficial for poorer learners. This indicates that structuring the learning time and the introduction of even a small portion of compulsory time for content-related question solving are beneficial, especially for poorer learners, with regard to exam scores.

\section{APPENDIX}

\section{Example Exam Questions}

Question 1: assessing knowledge. "Name the three parts of a nucleotide."

Question 2: comprehension and application. "Please describe the use of the 'baking' process in the Southern blot procedure."

Question 3: synthesis and evaluation. "On the spot of a murder, a cigarette is found. After thorough a police inquisition, two near relatives (two brothers) are suspected of committing the murder, and their DNA is submitted to a Southern blot. Please describe how it can be assured that the actual murderer is correctly identified."

\section{ACKNOWLEDGMENTS}

The authors thank all colleagues of the Ludwig-Erhard Berufskolleg for the help in setting up this study. The authors especially thank G. Reuter for revising the manuscript.

\section{DISCLOSURES}

No conflicts of interest, financial or otherwise, are declared by the author(s).

\section{AUTHOR CONTRIBUTIONS}

Author contributions: C.H.R. and E.N.R. conception and design of research; C.H.R. performed experiments; C.H.R. analyzed data; C.H.R. drafted manuscript; E.N.R. interpreted results of experiments; E.N.R. edited and revised manuscript.

\section{REFERENCES}

1. Armbruster P, Patel M, Johnson E, Weiss M. Active learning and student-centered pedagogy improve student attitudes and performance in introductory biology. CBE Life Sci Educ 8: 203-213, 2009.

2. Banerjee AC. Effect of lecture, and cooperative learning strategies on achievement in chemistry in undergraduate classes. Int J Sci Educ 19: 903-910, 1997.

3. Barkley E, Cross P, Major CH. Collaborative Learning Techniques. San Francisco, CA: Jossey-Bass, 2005.

4. Barr RB, Tagg J. From teaching to learning-a new paradigm for undergraduate education. Change 27: 13-25, 1995.

5. Berger R, Hänze M. Comparison of two small-group learning methods in 12th-grade physics classes focusing on intrinsic motivation and academic performance. Int J Sci Educ 31: 1511-1527, 2009.

6. Bery W. Surviving lecture. A pedagogical alternative. Coll Teach 56: 149-153, 2008.

7. Bowen CW. A quantitative literature review of cooperative learning effects on high school and college chemistry achievement. J Chem Educ 77: 116-119, 2000. 
8. Deci EL, Ryan RM. The "what" and "why" of goal pursuits: human needs and the self-determination of behavior. Psychol Inquiry 11: 227-268, 2000

9. Dolmans D, De Grave W, Wolfhaben I, Van der Vleuten C. Problembased learning: future challenges for educational practice and research. Med Educ 39: 732-741, 2005.

10. Handelsman J, Ebert-May D, Beichner R, Bruns P, Chang A, DeHaan R, Gentile J, Lauffer S, Stewart J, Tilghman SM, Wood WB. Education. Scientific teaching. Science 304: 521-522, 2004.

11. Harskamp E, Ding N. Structured collaboration versus individual learning in solving physics problems. Int J Sci Educ 28: 1669-1688, 2006.

12. Hartling L, Spooner C, Tjosvold L, Oswald A. Problem-based learning in pre-clinical medical education: 22 years of outcome research. Med Teach 32: 28-35, 2010.

13. Knight JK, Wood WB. Teaching more by lecturing less. Cell Biol Educ 4: 298-310, 2005

14. Kuh G, Kinzie J, Schuh J, Whitt E, Associates. Student Success in College: Creating Conditions That Matter. San Francisco, CA: JosseyBass, 2005.

15. Langendyk V. Not knowing that they do not know: self-assessment accuracy of third-year medical students. Med Educ 40: 173-179, 2006.

16. Lord TR. 101 reasons for using cooperative learning in biology teaching. Am Biol Teach 63: 30-38, 2001.

17. Mac Gregor J, Cooper J, Smith K, Robinson P. Strategies for Energizing Large Classes: From Small Groups to Learning Communities. San Francisco, CA: Jossey-Bass, 2000.
18. McClanahan E, McClanahan L. Active learning in non-majors biology class: lessons learned. Coll Teach 50: 92-96, 2002.

19. Michael J. Where's the evidence that active learning works? Adv Physiol Educ 30: 159-167, 2006.

20. Polyzois I, Claffey N, Mattheos N. Problem-based learning in academic health education. A systematic literature review. Eur J Dent Educ 14: 55-64, 2010.

21. Reinhardt C. Natura Biologie Fachhochschulreife. Stuttgart: Klett, 2009.

22. Richardson D. Don't dump the didactic lecture; fix it. Adv Physiol Educ 32: 23-24, 2008

23. Rider EA, Keefer CH. Communication skills: definitions and a teaching toolbox. Med Educ 40: 624-629, 2006.

24. Slavin RE, Hurley EA, Chamberlain A. Cooperative learning and achievement: theory and research. In: Handbook of Psychology: Educational Psychology, edited by Reynolds WM, Miller GE. New York: Wiley, 2003, vol. 7, p. 177-197.

25. Smith KA, Sheppard SD, Johnson DW, Johnson RT. Pedagogies of engagement: classroom-based practices. J Eng Educ 94: 87-101, 2005.

26. Sturm H, Bogner F. Student-oriented versus teacher centred: the effect of learning at workstations about birds and bird flight on cognitive achievement and motivation. Int J Sci Educ 7: 941-959, 2008.

27. Ventamiglia LM. Cooperative learning at the college level. In: Interactive Learning in the Higher Education Classroom, edited by Foyle C. Washington, DC: National Education Association, 1995.

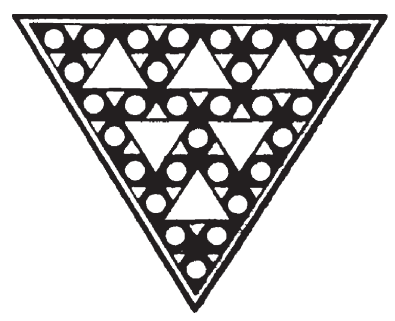

